\title{
KEMAMPUAN MENULIS TEKS ANEKDOT BERDASARKAN STRUKTUR DAN KEBAHASAAN
}

\author{
Nur Faradila Tsani ${ }^{1}$, Lisdwiana Kurniati ${ }^{2}$, Dwi Fitriyani ${ }^{3}$ \\ ${ }^{123}$ FKIP Universitas Muhammadiyah Pringsewu \\ Pos-el: faradila2tsani@gmail.com ${ }^{1}$, lisdwiana@stkip_mpl.ac.id², \\ dwifitriyani@umpri ac.id ${ }^{3}$
}

\begin{abstract}
Abstrak
Penelitian ini bertujuan untuk mengetahui kemampuan siswa kelas X SMA Negeri 2 Gadingrejo dalam menulis teks anekdot berdasarkan struktur dan kebahasaan. Metode penelitian yang digunakan dalam penelitian ini adalah metode penelitian kualitatif dimana untuk memahami fenomena tentang apa yang dialami oleh subjek penelitian terkait dengan kemampuan abstak sisecara holistic dan dengan cara deskriptif dalam bentuk kata-kata dan bahasa, pada suatu konteks khusus yang alamiah dan dengan memanfaatkan berbagai metode ilmiah. Populasi dalam penelitian ini sebanyak 30 sampel dalam satu kelas yaitu kelas X IPA 4 denganteknikpengambilansampelberupa cluster random sampling. Berdasarkan hasil analisis kemampuan siswa kelas X IPA 4 SMA Negeri 2 Gadingrejo dalam menulis teks anekdot berdasarkan struktur dan kebahasaan diperoleh nilai dengan kategori tinggi 2 siswa, perolehan nilai dengan kategori cukup 25 siswa, perolehan nilai dengan kategori kurang 3 siswa.

Kata Kunci:Teks Anekdot, Struktur, Kebahasaan.
\end{abstract}

\begin{abstract}
This study aims to determine the ability of class X students of SMA 2 Gadingrejo in writing anecdotal texts based on structure and language. The research method used in this study is a qualitative research method in which to understand the phenomena about what is experienced by research subjects related to the ability of abstraction holistically and in a descriptive way in the form of words and language, in a special natural context and by utilizing various scientific method. The population in this study were 30 samples in one class, namely class X IPA 4 with a sampling technique in the form of cluster random sampling. Based on the results of the analysis of the ability of students of class X IPA 4 of SMA Negeri 2 Gadingrejo in writing anecdotal texts based on structure and language, scores were obtained with a high category of 2 students, acquisition of grades with a sufficient category of 25 students, acquisition of grades with less categories of 3 students. Keywords: Anecdotal Text, Structure, Language.
\end{abstract}

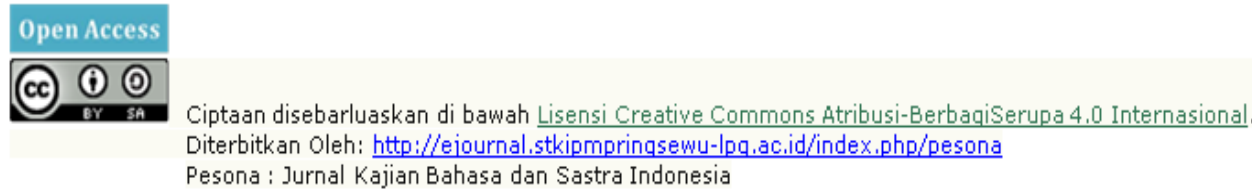




\section{PENDAHULUAN}

Pembelajaran bagi manusia sangat penting karena dengan dilakukannya proses pembelajaran manusia akan mampu berkembang. Selanjutnya, proses pembelajaran dapat dilakukan dengan adanya interaksi pendidik dengan peserta didik. Dalam pembelajaran diperlukan satuan mata pelajaran sebagai indikator proses pembelajaran sesuai dengan disiplin ilmu tertentu agar mempermudah pencapaian proses pembelajaran yang sesuai dengan bidangnya. Pembelajaran merupakan interaksi antara pendidik, peserta didik dan sumber belajar pada suatu lingkungan belajar agar dapat terjadi proses pemerolehan ilmu dan pengetahuan, serta pembentukan sikap dan kepercayaan pada peserta didik (Amri dalam Eka Sofia Agustina dkk., 2016: 10).

Pada proses pembelajaran diperlukan bahasa sebagai alat interaksi antar komponen sekolah untuk menyampaikan pesan atau informasi. Begitu penting peranan bahasa pada pembelajaran. Bahasa Indonesia merupakan salah satu mata pelajaran yang diajarkan di sekolah. Berdasarkan kurikulum 2013 ruang lingkup mata pelajaran Bahasa Indonesia mencakup komponen kemampuan berbahasa yang harus diajarkan dan dimiliki oleh peserta didik yang meliputi: menyimak, berbicara, membaca dan menulis. Keempat keterampilan berbahasa tersebut saling memiliki hubungan keterkaitan. Salah satu dari keempat keterampilan yang diajarkan adalah keterampilan menulis.

Menulis merupakan kegiatan melahirkan ide dan mengemas ide itu ke dalam bentuk lambang-lambang grafis berupa tulisan yang bias dipahami orang lain (Nurhadi, 2017: 5). Dalam menulis seseorang melakukan suatu aktifitas untuk menghasilkan suatu produk berupa rangkaian terstruktur lambang-lambang grafis suatu bahasa yang mengandung makna yang diikat dalam satu kesatuan ide yakni tulisan. Tulisan itu digunakan untuk mengekspresikan diri dan mengomunikasikan ide kepada orang lain secara tidak langsung. Menulis juga merupakan sebuah aktivitas berpikir. Proses berpikir dalam menulis mencakup bagaimana ide sebagai gagasan atau pesan yang disampaikan dan bahasa tulis sebagai tempat yang mewadahi ide relevan serta saling berkaitan sehingga dari sebuah tulisan dapat diselami cara berpikir seseorang.

Berdasarkan kurikulum 2013 proses pembelajaran memiliki tujuan melahirkan hasil belajar pada peserta didik yang produktif, kreatif, inovatif, dan efektif melalui penguatan sikap, keterampilan, dan pengetahuan yang terintegrasi. Sesuai dengan indikator pencapaian kompetensi 
pada matapelajaran Bahasa Indonesia kelas X kurikulum 2013 yaitu menyusun teks anekdot sesuai dengan struktur dan kebahasaan, maka materi pembelajaran yang diajarkan adalah menulis teks anekdot.

Teks anekdot adalah cerita singkat dan lucu yang digunakan untuk menyampaikan kritik melalui sindiran lucu terhadap kejadian yang menyangkut orang banyak atau perilaku tokoh publik (Suherli dkk, 2017:103). Pada kegiatan menulis, kita dapat mengekspresikan semua yang ada di dalam pikiran kita. Menulis juga mampu membuat seseorang menjadi kreatif dan dengan menulis kita mampu menyampaikan apa yang ada dalam hati, dan otak kita ke dalam bentuk tulisan. Begitu juga dengan pembelajaran memproduksi teks anekdot dan khususnya pada anak didik yang nantinya akan dituntut untuk mengembangkan keterampilannya yaitu membuat atau menulis teks anekdot. Berkenaan dengan menulis teks anekdot dalam kurikulum 2013 peserta didik belum memahami bagaimana menulis teks anekdot berdasarkan struktur dan kebahasaan dalam indikator pencapaian, sehingga perlu adanya pengenalan dan pendalaman materi tentang anekdot.

Berdasarkan observasi dan wawancara peneliti dengan guru mata pelajaran Bahasa Indonesia di SMA Negeri 2 Gadingrejo yaitu Ibu Dina Oktaviana, S.Pd. pada hari
Senin tanggal 5 Oktober 2019, peneliti mendapatkan data sebagai berikut: Materi teks anekdot yang diajarkan sudah berjalan dengan baik, sesuai dengan RPP dan Silabus yang dirancang. Sarana dan prasarana juga sudah memadai seperti perpustakaan, buku pelajaran Bahasa Indonesia, LCD dan halhal yang menunjang lainnya. Akan tetapi pada kenyataannya sebagian besar dari siswa di dalam kelas masih belum mampu untuk menuliskan teks anekdot sesuai struktur dan kaidah kebahasaan. Berdasarkan informasi yang diutarakan oleh Ibu Dina Oktaviana, S.Pd. sebagian dari siswa tersebut memang masih mengalami kesulitan dalam menuliskan teks anekdot karena kurangnya minat siswa dalam menulis dan mengetahui struktur pada isi anekdot. Kurangnya minat membaca pada diri siswa juga menjadi faktor menghambat untuk menuliskan teks anekdot dan kurangnya wawasan siswa pada kebahasaan anekdot menjadi faktor kesulitan siswa dalam menuliskan teks anekdot.

Rumusan masalah dalam penelitian ini adalah bagaimana kemampuan menulis teks anekdot yang sesuai dengan struktur dan kebahasaan pada siswa kelas X IPA SMA Negeri 2 Gadingrejo. Subjek penelitian ini adalah siswa kelas X IPA 4 SMA Negeri 2 Gadingrejo. Penelitaian dilakukan di semester satu (ganjil). 


\section{METODE PENELITIAN}

Penelitian ini dilaksanakan di SMA Negeri 2 Gadingrejo yang beralamatkan di Jalan Ki HajarDewantara, Gadingrejo, Way Lima, Kabupaten Pringsewu, Lampung 35367. Lokasi tersebut dipilih karena tempat dekat dengan tempat peneliti, sehingga memudahkan dalam melakukan penelitian.

Populasi dalam penelitian ini adalah seluruh siswa kelas X semester ganjil SMA Negeri 2 Gadingrejo tahun pelajaran 20192020 sebanyak 123 siswa.

Sehubungan banyaknya populasi, maka peneliti mengambil sampel sesuai kebutuhan dan tujuan dalam penelitian. Terkait dengan alas an tersebut maka yang menjadi sampel dalam penelitian ini diambil $25 \%$ atau sebanyak 32 siswa.

Dalam penelitian ini, peneliti menggunakan teknik sampling yang berupa cluster random sampling. Cluster random sampling atau sampling acak kelompok merupakan teknik sampling yang dipilih. Peneliti mengambil satu kelas secara acak dari seluruh kelas X SMA Negeri 2 Gadingrejo semester ganjil tahun pelajaran 2019-2020, dan terpilih kelas X IPA 4 dengan jumlah 32 siswa sebagai objek penelitian. Teknik dan alat pengumpulan data yang digunakan oleh peneliti sebagai berikut:

\section{1) Observasi}

Menurut Maolani dan Cahyana (2016: 148) observasi atau pengamatan merupakan suatu teknik atau cara pengumpulan data dengan jalan mengadakan pengamatan terhadap kegiatan yang sedang berlangsung. Langkah- langkah yang harus dilakukan dalam melakukan observasi

a. Ketahui dan tentukan lebih dahulu apa yang perlu diobservasi.

b. Selidiki tujuan-tujuan yang umum maupun khusus dari masalah-masalah untuk menentukan apa yang harus diobservasi.

c. Buatlah suatu cara untuk mencatat hasil observasi.

d. Adakan dan batasai dengan tegas macam-macam tingkat kategori yang akan digunakan.

e. Adakan observasi secermat-cermatnya.

f. Catatlah tiap-tiap gejala secara terpisah.

g. Ketahuilah baik-baik alat-alat pencatatan dan tata caranya mencatat sebelum melakukan observasi (Admin, 2015: 1).

2) Tes

Menurut Arikunto (2010: 193) Tes adalah serentetan pertanyaan atau latihan serta alat lain yang digunakan untuk mengukur keterampilan, pengetahuan intelegensi, kemampuan atau bakat yang dimiliki oleh individu atau kelompok. 
Teknik pemeriksaan keabsahan data yang digunakan dalam penelitian ini yaitu uji credibility dengan cara meningkatkan ketekunan serta menggunakan bahan referensi.

Teknik analisis data pada penelitian ini dilakukan dengan cara mengumpulkan datadata yang diperoleh dari hasil observasi, wawancara dan tes, kemudian menganalisis seluruh data sesuai yang diperoleh, setelah itu mengidentifikasikan data sesuai dengan Kemampuan Menulis Teks Anekdot Berdasarkan Struktur dan Kebahasaan Siswa Kelas X Semester Ganjil SMA Negeri 2 Gadingrejo Tahun Pelajaran 20192020 .

\section{HASIL DAN PEMBAHASAN}

Berdasarkan data hasil rekapitulasi skor kemampuan menuliskan teks anekdot berdasarkan struktur dan kebahasaan (pada penyajian data) diperoleh 30 sampel terdapat 3 sampel (sekitar 10) yang dikategorikan kurang, 25 sampel (sekitar 83,3) dikategorikan cukup, 2 sampel (sekitar 6,7) dikategorikan baik. Tidak ada sampel dikategorikan sangat baik dan gagal.

\begin{tabular}{|c|l|c|c|}
\hline No. & Kategori & JumlahSiswa & Presentase \\
\hline 1. & Kurang & 3 siswa & $10 \%$ \\
\hline 2. & Cukup & 25 siswa & $83,3 \%$ \\
\hline 3. & Baik & 2 siswa & $6,7 \%$ \\
\hline
\end{tabular}

\begin{tabular}{|c|c|c|}
\hline Jumlah & 30 siswa & $100 \%$ \\
\hline Analisis kemampuan siswa dalam
\end{tabular}
menuliskan teks anekdot berdasarkan struktur dan kebahasaan siswa kelas X IPA semester 1 SMA Negeri 2 Gadingrejo tahun pelajaran 2019-2020 yaitu:

\section{a. Kategori Sangat Baik}

Siswa yang memperoleh nilai dengan kategori sangat baik (85-100) sebanyak 0 siswa.

\section{b. Kategori Baik}

Siswa yang memperoleh nilai dengan kategori baik (75-84) berjumlah 2 siswa.

1) nilai 76,9 dengan kategori baik. dengan rincian skor pada setiap indikator sebagai berikut: Struktur teks anekdot mendapat skor 3 karena mampu menuliskan dengan tepat 5 struktur tersebut. Kebahasaan teks anekdot: (1) Kalimat yang menyatakan peristiwa masa lalu, mendapat skor 1 karena hanya mampu menuliskan 1 kalimat tersebut. (2) Kalimat retoris, mendapat skor 0 karena tidak mampu menuliskan kalimat tersebut. (3) Konjungsi yang menyatakan hubungan waktu, mendapat skor 3 karena mampu menuliskan 3 konjungsi tersebut. (4) Penggunaan kata kerja aksi, mendapatkan skor 3 karena 
mampu menggunakan 3 kata kerja aksi dengan tepat. (5) Kalimat perintah, mendapatkan skor 1 karena mampu menuliskan 1 kalimat perintah dengan tepat. (6) Kalimat Seru, mendapatkan skor 1 karena hanya mampu menuliskan 1 kalimat seru dengan tepat. Ejaan bahasa Indonesia: (1) Penggunaan huruf kapital, mendapat skor 3 karena sudah tepat sesuai dengan penggunaannya.(2) Penggunaan Tanda Baca, mendapatkan skor 2 karena terdapat 11 tanda baca yang cukup tepat menggunakannya.

2) Pada siswa kedua dengan rincian: Struktur Teks Anekdot Mendapat skor 3 karena mampu menuliskan dengan tepat 5 struktur tersebut. Kebahasaan Teks Anekdot: (1) Kalimat yang MenyatakanPeristiwa Masa Lalu, mendapat skor 1 karena hanya mampu menuliskan 1 kalimattersebut.

Kalimat Retoris, mendapat skor 1 karena hanya mampu menuliskan 1 kalimat tersebut. (3) Konjungsi yang Menyatakan Hubungan Waktu, mendapat skor 3 karena mampu menuliskan 3 konjungsi tersebut. (4) Penggunaan Kata Kerja Aksi, mendapatkan skor 1 karena hanya mampu menuliskan 1 kata kerja aksi dengan tepat. (5) Kalimat Perintah, mendapatkan skor 2 karena mampu menuliskan 2 kalimat perintah dengan tepat. (6) Kalimat Seru, mendapatkan skor 1 karena hanya mampu menuliskan 1 kalimat seru dengan tepat. Ejaan Bahasa Indonesia: (1) Penggunaan Huruf Kapital, mendapat skor 3 karena sudah tepat sesuai dengan penggunaannya. (2) Penggunaan Tanda Baca, mendapatkan skor 2 karena terdapat 11 tanda baca yang cukup tepat menggunakannya.

\section{c. Kategori Cukup}

Siswa yang memperoleh nilai dengan kategori cukup (60-74) berjumlah 25 siswa. Berikut dua hasil siswa yang mendapat nilai dengan kategori cukup.

1) Struktur Teks Anekdot: Mendapat skor 3 karena mampu menuliskan dengan tepat 5 struktur tersebut. Kebahasaan Teks Anekdot: (1) Kalimat yang Menyatakan Peristiwa Masa Lalu, mendapat skor 1 karena hanya mampu menuliskan 1 kalimat tersebut. (2) Kalimat Retoris, mendapat skor 0 karena tidak mampu menuliskan kalimat tersebut. (3) Konjungsi yang Menyatakan Hubungan Waktu, mendapat skor 2 karena mampu menuliskan 2 konjungsi tersebuts. (4) Penggunaan Kata Kerja Aksi, mendapatkan skor 3 karena mampu 
menuliskan 3 kata kerja aksi dengan tepat. (5) Kalimat Perintah, mendapatkan skor 0 karena tidak mampu menuliskan kalimat perintah. (6) Kalimat Seru, mendapatkan skor 1 karena hanya mampu menuliskan 1 kalimat seru dengan tepat.Ejaan Bahasa Indonesia: (1) Penggunaan Huruf Kapital,mendapat skor 2 karena sudah tepat sesuai dengan penggunaannya.(2) Penggunaan Tanda Baca, mendapatkan skor 1 karena terdapat 10 tanda baca yang tepat menggunakannya.

2) Pada hasil kedua struktur teks nekdot mendapat skor 3 karena mampu menuliskan dengan tepat 5 struktur tersebut. Kebahasaan Teks Anekdot: (1) Kalimat yang Menyatakan Peristiwa Masa Lalu, mendapat skor 1 karena hanya mampu menuliskan 1 kalimat tersebut. (2) Kalimat Retoris, mendapat skor 1 karena hanya mampu menuliskan 1 kalimat tersebut. (3) Konjungsi yang Menyatakan Hubungan Waktu, mendapat skor 1 karena mampu menuliskan 1 konjungsi tersebut. (4) Penggunaan Kata Kerja Aksi, mendapatkan skor 2 karena hanya mampu menuliskan 2 kata kerja aksi dengan tepat. (5) Kalimat Perintah, mendapatkan skor 0 karena tidak mampu menuliskan kalimat perintah.
(6) Kalimat Seru, mendapatkan skor 1 karena hanya mampu menuliskan 1 kalimat seru dengan tepat.Ejaan Bahasa Indonesia: (1) Penggunaan Huruf Kapital,mendapat skor 3 karena sudah tepat sesuai dengan penggunaannya.(2) Penggunaan Tanda Baca, mendapatkan skor 1 karena dapat menggunakan 10 tanda baca dengan tepat.

\section{d. Kategori Kurang}

Siswa yang memperoleh nilai dengan kategori kurang (40-59) berjumlah 3 siswa.

1) Struktur Teks Anekdot mendapat skor 3 karena mampu menuliskan dengan tepat 5 struktur tersebut. Kebahasaan Teks Anekdot: (1) Kalimat yang Menyatakan Peristiwa Masa Lalu, mendapat skor 1 karena hanya mampu menuliskan 1 kalimat tersebut. (2) Kalimat Retoris, mendapat skor 0 karena tidak mampu menuliskan kalimat tersebut. Konjungsi yang Menyatakan Hubungan Waktu, mendapat skor 0 karena tidak mampu menuliskan konjungsi tersebut. (4) Penggunaan Kata Kerja Aksi, mendapatkan skor 1 karena hanya mampu menuliskan 1 kata kerja aksi dengan tepat. (5) Kalimat Perintah, mendapatkan skor 0 karena tidak mampu menuliskan kalimat perintah dengan tepat. (6) Kalimat Seru, 
mendapatkan skor 1 karena hanya mampu menuliskan 1 kalimat seru dengan tepat.Ejaan Bahasa Indonesia: (1) Penggunaan Huruf Kapital,mendapat skor 3 karena sudah tepat sesuai dengan penggunaannya.(2) Penggunaan Tanda Baca, mendapatkan skor 1 karena terdapat 8 tanda baca yang tepat menggunakannya.

2) Struktur Teks Anekdot: Mendapat skor 3 karena mampu menuliskan dengan tepat 5 struktur tersebut. Kebahasaan Teks Anekdot: (1) Kalimat yang Menyatakan Peristiwa Masa Lalu, mendapat skor 0 karena tidak mampu menuliskan kalimat tersebut.

Kalimat Retoris, mendapat skor 0 karena tidak mampu menuliskan kalimat tersebut. (3) Konjungsi yang Menyatakan Hubungan Waktu, mendapat skor 0 karena tidak mampu menuliskan konjungsi tersebut. (4) Penggunaan Kata Kerja Aksi, mendapatkan skor 1 karena hanya mampu menuliskan 1 kata kerja aksi dengan tepat. (5) Kalimat Perintah, mendapatkan skor 1 karena hanya mampu menuliskan 1 kalimat perintah dengan tepat. (6) Kalimat Seru, mendapatkan skor 1 karena hanya mampu menuliskan 1 kalimat seru dengan tepat.Ejaan Bahasa Indonesia:
(1) Penggunaan Huruf Kapital,mendapat skor 3 karena sudah tepat sesuai dengan penggunaannya.(2) Penggunaan Tanda Baca, mendapatkan skor 2 karena terdapat 12 tanda baca yang tepat menggunakannya.

3) Siswa ketiga mendapat nilai dengan kategori kurang dengan rincian: struktur teks anekdot Mendapat skor 3 karena mampu menuliskan dengan tepat 5 struktur tersebut. Kebahasaan Teks Anekdot: (1) Kalimat yang Menyatakan Peristiwa Masa Lalu, mendapat skor 0 karena tidak mampu menuliskan kalimat tersebut. (2) Kalimat Retoris, mendapat skor 0 karena tidak mampu menuliskan kalimat tersebut. (3) Konjungsi yang Menyatakan Hubungan Waktu, mendapat skor 1 karena hanya mampu menuliskan 1 konjungsi tersebut. (4) Penggunaan Kata Kerja Aksi, mendapatkan skor 3 karena mampu menuliskan 3 kata kerja aksi dengan tepat. (5) Kalimat Perintah, mendapatkan skor 0 karena tidak mampu menuliskan kalimat perintah dengan tepat. (6) Kalimat Seru, mendapatkan skor 0 karena tidak mampu menuliskan kalimat seru dengan tepat.Ejaan Bahasa Indonesia:

Penggunaan Huruf Kapital,mendapat skor 1 karena 1 yang tepat sesuai dengan 
penggunaannya.(2) Penggunaan Tanda

Baca, mendapatkan skor 1 karena terdapat 6 tanda baca yang tepat menggunakannya.

\section{e. Kategori Gagal}

Siswa yang memperoleh nilai dengan kategori kurang (0-39) berjumlah 0 siswa.

\section{SIMPULAN}

Berdasarkan hasil analisis data penelitian yang telah peneliti lakukan dapat disimpulkan bahwa nilai akhir kemampuan siswa dalam menulis teks anekdot berdasarkan struktur dan kebahasaan didapat bahwa 30 sampel yang peneliti ambil pada siswa kelas X IPA semester ganjil SMA Negeri 2 Gadingrejo Tahun Pelajaran 2019-2020, terdapat 3 siswa dikategorikan kurang, 25 siswa dikategorikan cukup, 2 siswa dikategorikan baik, dan tidak ada siswa yang dikategorikan sangat baik dan gagal.

Dengan memperhatikan jumlah skor yang dicapai maka dapat dihitung kemampuan rata-rata dalam menuliskan teks anekdot berdasarkan struktur dan kebahasaan pada siswa kelas X IPA semester I SMA Negeri 2 Gadingrejo Kabupaten Pringsewu, yaitu: $P=\frac{399}{900} \times 100$ $=44,3$. Dengan demikian, skor rata-rata siswa 44,3 dapat dipahami bahwa rata-rata kemampuan siswa dalam menuliskan teks anekdot berdasarkan struktur dan kebahasaan berada pada interval 40-59 termasuk dalam kategori kurang.

\section{DAFTAR PUSTAKA}

Eka Sofia Agustina, dkk.. (2016). Pola Penyajian Kegiatan Pembelajaran Berbasis Pendekatan Ilmiah (Saintific Approach). Yogyakarta: Media Akademi.

Maolani, Rukaesih. (2016). Metodologi Penelitian Pendidikan. Edisi 1. Cetakan ke 2. Jakarta: Rajawali Pers.

Nurhadi. (2017). Handbook of Writing (Panduan Lengkap Menulis). Jakarta: Bumi Aksara.

Suharsimi Arikunto. (2010). Prosedur Penelitian: Suatu Pendekatan Praktik. Jakarta: Rineka Cipta.

Suherli, dkk.. (2017). Bahasa Indonesia. Edisi Revisi. Jakarta: Kemendikbud. 